\title{
The Strategies on the Application of Cooperative Teaching in College English Based on ESP
}

\author{
WANG Bing \\ Leshan Normal University, Leshan, China
}

\begin{abstract}
The English for specific purposes (ESP) teaching mode has been adopted in College English teaching in many colleges and universities nowadays and it has many advantages in contrast to the traditional teaching mode. And the application of the cooperative teaching can strengthen the teaching effect in ESP teaching. So, the paper tries to put forward some strategies for it after a brief introduction to the ESP, status-quo of traditional College English class and the significance of the application.
\end{abstract}

Keywords: strategies, application, cooperative teaching, College English

\section{Introduction}

With the development of Internet, the traditional College English teaching mode in universities has been converted into the ESP mode in which more flexible teaching methods can be adopted. In such condition, new teaching method needs to be explored in the College English course. The cooperative teaching is widely used recently in College English teaching. The application of this kind of teaching method can play a significant role in improving the teaching quality and student's comprehensive qualities if it can be properly utilized base on student's learning in the teaching process.

\section{The Brief Introduction to ESP}

ESP, abbreviation for English for special purpose, which came into being in the Western countries in 1960s as a branch of English language teaching, is brought about as a concept in opposition to English for general purpose (EGP) or the Basic English. Just as Hutchinson (1987) put, "ESP is a kind of English that is relevant to a particular career or a certain subject. And this kind of English course caters to the leaner's specific intentions and needs" (p. 8). So, the purpose of ESP teaching is to develop the student's ability to apply the English into their majors and it meets the different learning purposes and the needs for actual application for different students. As a transdisciplinary research, it is not only related to the English language and linguistics, but also closely associated with the students' knowledge in a particular subject.

The theory of cooperative learning appears in America in 1970s and becomes the center of attention all over the world as a mainstream teaching theory and strategy. In the late 1980s, the real research of cooperative learning has begun and produced some achievements, greatly promoting the domestication and improvement of the theory. However, the definition of cooperative learning has not been reached unanimously by now in the academic circle. But Johnson holds the view that cooperative learning is the learning in which groups are used

WANG Bing, Master, associate professor, Foreign Language School, Leshan Normal University, Leshan, China. 
to involve all the students in the teaching to promote their learning to the greatest extent (Zhao, 2020). In our country, the cooperative teaching has been put forward that as a teaching activity. Cooperative learning, based on groups-the basic organization form, takes advantage of the interactions between dynamic elements in the teaching to advance the students' learning so as to achieve the teaching objectives through the evaluation standard which emphasizes the team as a whole.

From the above, we can see, in essence, the cooperative learning is kind of origination for teaching. The students study all along as different groups, support mutually for a common goal, and accomplish the learning tasks together with the teacher's planning and organization.

\section{The Status Quo of the Traditional College English Class}

In recent years with the development of Internet and globalization, the traditional College English teaching modes cannot meet the needs from English learners. It must be reformed. But due to the restriction from the traditional beliefs, there are still some problems in the College English teaching which needs to be reformed effectively on the long-term basis.

In the traditional College English class, teachers do the most job of explanation while students stay passive receiving the knowledge, which is hard to arouse and enhance their learning interests. Taking the College English Comprehensive Course (traditionally, the Intensive Reading Course) as an example, the teacher tends to adopt the traditional teaching method-from the new words explanation, the passage translation to the excises after class. In this teaching mode, teachers and students lack the necessary interactions, let alone the interaction between students (Li, 2019). Student's initiatives and creation ability cannot be displayed and utilized, which cannot contribute to improving the students' comprehensive English ability.

\section{The Significance of Application of Cooperative Teaching in College English}

During the process of student's self-learning, it is hard for them to master the complicated English language points and so much grammar, syntax, etc. and to apply what they have learned to practice, only relying on teacher's explanation in order to achieve the teaching objectives. Through the cooperative teaching, students can interact with and help each other to cultivate their cooperative spirits. The cooperative teaching lays an emphasis on the student's individuality and is beneficial to developing the student's exploring spirit, enriching the teaching content and improving the student's learning interest in the relaxing atmosphere (Liu, 2020). The cooperative teaching breaks the mold of the traditional teaching mode, develops the student's team awareness, and makes them experience the happiness brought about by the cooperative teaching.

\section{The Strategies for the Application of Cooperative Teaching in College English}

\section{To Take Advantage of Cooperative Teaching Flexibly}

Teachers play the leading role in the classroom teaching and should have much knowledge about the cooperative form. They should instruct the student according to the teaching content while the student plays the major part in the teaching. Their learning and character produce a certain impact on the cooperative learning in groups. Therefore, teachers should communicate with the students to know the accurate information about them in detail. Teachers should get a deep understanding about the group learning and get student's feedback (Dong, 2016). What's more, teachers should make it clear what the student can acquire through this kind of teaching mode in terms of knowledge and skill. Only when the guidance before the teaching is fully prepared, can the 
student's comprehensive English ability be enhanced. For example, when students learn the relatively basic grammar points, the group can be formed by means of their seat positions or their willingness. In this case, students can adapt themselves to the group learning because they are more willing to choose those who are familiar to them as the group members. When the students learn the texts, groups can be formed according to the student's learning scores and English levels. As for those students who are introverted, the extroverted students can be paired with them to form a group and some inspiring measures can be taken to encourage them. The group members should be replaced regularly to avoid too much fractions and conflict among them. What's more, it can create the opportunity for the group members to cooperate with others. Every student should be integrated into the group cooperation as deeply as possible.

\section{To Combine Cooperation and Competition between Students}

The cooperative teaching literally is to achieve the teaching objects through the cooperation. During the cooperative teaching, the teaching content can be split and the tasks should be assigned according to the students' learning condition and character (Li, 2019). After finishing the tasks, the group members should have a discussion in which they can share the experience with each other to enhance the cooperation. In each group, a group leader can be appointed and the teachers assign them tasks which are reassigned to the group members according to their character. But during the cooperative teaching, competition between group members is also important. It can arouse the students' learning initiative. Teachers can design some questions from several dimensions and cause the competition to come into being among groups. The winner can be the one who answers the question correctly with the least time. The winning group should be rewarded while other groups should be encouraged accordingly. Teachers should balance the relationship between cooperation and competition to play the cooperative learning to its greatest effect.

\section{To Play the Teachers' Leading Role Fully}

The class time is limited for College English teaching and the teacher should choose the important texts or grammar points. First, the teacher should be careful of the difficulty of the teaching content, allowing it to be suitable for all the students. Second, the content for the cooperative teaching should be closely related to the teaching materials. Teachers can make students discuss the exercise after each class to deepen the understanding about the texts. Also, the learned knowledge can be reviewed before the new knowledge which is about to learn. The teacher should point out the student's errors during the cooperative teaching process and help them correct these errors to advance the efficiency in the cooperative learning. In the preview phase, teachers put forward some questions, leaving time for students to think and prepare. After that, the teacher should help the students to recall the relevant knowledge to introduce the major points that need to be learned. In the cooperative learning process, the teacher should keep an eye on the students' cooperation. If there is any problem, point it out and assist the students in consolidating the knowledge they have learned. Lastly, in the exercise phase after class, the teacher should have a clear knowledge about the student's completion of the exercise and the mastery of the knowledge. Help those who have any problems to modify the errors so as to improve their marks.

\section{To Establish the Reasonable Evaluation System}

The college students are a little hostile to the school regulations and the teacher's arrangement in the class. In their competition, it is more likely that they will compete with each other as if they are fighting a battle in the battlefield when they are in the classroom and they are unwilling to admit their failure. Some of them even 
complain that the teacher is unfair. As for that, the teacher should establish the scientific and reasonable assessment standards to regulate the students' behaviors. The reasonable assessment standard can be used to audit the student's cooperation. In the teaching process, teachers should set the reasonable goals based on the students' individuality. Too hard a goal makes students feel the great pressure while an easy goal will make it lose the nature of being challenging. Teachers should design an evaluation system in all aspects according to the student's learning objectives. Firstly, it is the mutual evaluation within the group because the students in the group are familiar with each other and they can give an objective assessment. Secondly, it is the mutual evaluation between groups because they have observed and learned from each other and their assessment about others in other groups can be to the point. Lastly, it is the final evaluation from teachers after teachers analyze the evaluations mentioned above. Teachers should praise the students' strong points and point out the weak points and instruct the students to modify them.

\section{Conclusion}

In all, the cooperative teaching achieves the teaching goal by creating the active learning atmosphere and efficient learning situation through the cooperation between teachers and students as well as between students with the group activities as the basic teaching form. By means of cooperative teaching, teachers can play the students' learning potential fully and make students learn actively. The teacher should involve all the students in the group discussion to express their ideas in order to establish the harmonious relationships between teachers and students. So, the application of cooperative teaching is beneficial to the College English teaching based on ESP as long as the teachers effectively carry out the strategies mentioned above. It can assist in changing the current situation in the traditional teaching mode and will help improve the College English teaching effect to develop the students' comprehensive English ability and deepen the their understanding about the knowledge in their majors by English and finally enhance their ability to master the new knowledge through the English language as a tool.

\section{References}

Dong, X. (2016). The cooperative learning and College English teaching reform. Course Education Research, (28), G64.

Li, W. (2019). The problems and strategies for ESP teaching in universities. Overseas English, (21), 15.

Li, Y. (2020). The application of cooperative learning in College English teaching. Overseas English, (1), 65.

Liu, W. X. (2020). The application of cooperative learning in English teaching in higher education. Education Teaching Forum, (16), 139.

Hutchinson, T. (1987). A English for specific purposes: A learning-centered approach. Cambridge: Cambridge University Press. Zhao, J. (2020). The analysis of the problems and the strategies in ESP teaching in College English teaching reform. Course Education Research, (8), 35. 